Original Research Paper

\title{
Pemanfaatan Nilai Ekologi Ekosistem Mangrove Sebagai Sumber Belajar IPA di SMAN 3 Lembar
}

\author{
Zulhalifah $^{1 *}$, Jami'atul Aulia ${ }^{1}$, Ayu Safitri Melita ${ }^{1}$, Abdul Syukur ${ }^{1}$ \\ ${ }^{1}$ Program Studi Magister Pendidikan IPA, Pascasarjana Universitas Mataram, Indonesia
}

DOI: https://doi.org/10.29303/jpmpi.v4i2.662

Sitasi: Zulhalifah., Aulia, J., Melita, A. S. \& Syukur, A. (2021). Pemanfaatan Nilai Ekologi Ekosistem Mangrove Sebagai Sumber Belajar IPA di SMAN 3 Lembar. Jurnal Pengabdian Magister Pendidikan IPA, 4(2)

\section{Article History}

Received: 03 Februari 2021

Revised: 08 Maret 2021

Accepted: 06 April 2021

*Corresponding Author:

Zulhalifah,

Program Studi Magister

Pendidikan IPA, Pascasarjana

Universitas Mataram, Indonesia

Email: zulhalifah547@gmail.com

\begin{abstract}
Mangrove memiliki berbagai macam manfaat salah satunya dapat di jadikan sumber belajar dalam pembelajaran IPA. Pengabdian ini dilakukan dengan tujuan meningkatkan pemahaman peserta didik tentang ekosistem mangrove dan memanfaatkan lingkungan sekitar sebagai sumber belajar. Kegiatan pengabdian dilakukan dengan metode ceramah, diskusi dan tanya jawab dengan peserta didik. Kemudian LKPD dan angket dibagikan kepada peserta didik untuk disi. Hasil post test dianalisis dengan rating scale sehingga dapat diketahui kegiatan pengabdian yang dilakukan sangat baik bagi peserta didik dalam materi ekosistem mangrove. Beradasarkan hasil post test pada peserta didik pengabdian yang dilakukan sangat baik karena dapat menambah wawasan peserta didik terkait ekosistem mangrove. Selain itu, melatih peserta didik menggunakan lingkungan sekitar sebagai sumber belajar IPA.
\end{abstract}

Keywords: LKPD; Ekosistem Mangrove; Sumber Belajar

\section{Pendahuluan}

Indonesia memiliki keanekaragaman hayati tertinggi di dunia (mega biodiversity). Salah satunya keanekaragaman hayati pesisir yang terdiri dari berbagai bentuk ekosistem, diantaranya adalah ekosistem mangrove. Ekosistem mangrove tersusun atas komponen abiotik (suhu, air, cahaya, kelembapan, udara, pH dan lain-lain) dan biotik (mangrove, molusca, ikan, burung dan lain-lain). Hutan mangrove adalah kumpulan berbagai jenis spesies mangrove yang ada di sepanjang pantai atau muarai sungai. Hutan mangrove memiliki sumber daya alam yang harus dilestarikan. Hutan mangrove termasuk kawasan konservasi untuk mempertahankan fungsi ekologis. Mangrove memiliki kemampuan asimilasi dan laju penyerapan karbon yang tinggi (Donato et al. 2012). Hasil penelitian Donato et al. 2012, menyatakan 25 lokasi mangrove di IndoPasifik salah satu hutan terkaya karbon dan mengandung sekitar $1.023 \mathrm{Mg}$ karbon perhektar.

Hutan mangrove dapat berfungsi mencegah abrasi yang terjadi di daerah pesisir. Selain itu, ekosistem mangrove memiliki fungsi ekologi dan fungsi ekonomi. Fungsi ekologi ekosistem mangrove menyediakan jasa lingkungan sebagai tempat pengkajian konsep ekologi dari berbagai pihak. Salah satunya sebagai sumber belajar langsung bagi peserta didik untuk memahami konsep di bidang IPA. Adanya fungsi ekologi ini secara tidak langsung dapat menjadikan ekosistem mangrove memiliki fungsi pendidikan yaitu sebagai sumber belajar. Ekologi mangrove dapat menjadi materi dalam pembelajaran IPA seperti ekosistem, adaptasi makhluk hidup dan identifikasi bagian tumbuhan. Lingkungan memiliki keunikan tersendiri untuk menjadi 
sumber belajar sehingga memotivasi peserta didik dalam kegiatan pembelajaran (Saputri et al, 2019). Selain itu, sumbe belajar harus memfasilitasi peserta didik dengan aktivitas pembelajarna yang memanfaatkan potensi lokal (Yokhebed, 2016).

Ilmu Pengetahuan Alam pada hakikatnya terdiri dari empat komponen yaitu sikap ilmiah, proses ilmiaih, produk ilmiah dan aplikasi. Pembelajaran IPA menggunakan cara pengumpulan dan analisis data secara kritis, menyajikan dan menguji hipotesies dan kesimpulan mengenai data yang dikumpulkan. Ekosistem salah satu konsep yang menjadi bagian dalam pembelajaran IPA bagi peserta didik diberbagai jenjang pendidikan. Ekosistem adalah hubungan timbal balik yang terjadi antara komponen abiotic dan biotik. Bentuk timbal balik yang terjadi dalam suatu ekosistem dimulai dari interaksi paling sederhana sampai kompleks. Proses pembelajaran IPA tidak hanya dilakukan di dalam laboratorium saja, tetapi dapat dilakukan diruangan terbuka. Salah satunya pembelajaran IPA berbasis lingkungan yang dapat meningkatkan mutu pendidikan dengan memanfaatkan lingkungan sekitar seperti kawasan pesisir. Pembelajaran IPA melalui pembelajaran berbasis lingkungan diharapkan mutu pendidikan dengan memanfaatkan lingkungan. Pembelajaran dengan lingkungan sekitar dapat menumbuhkan softskills mengarahkan ke arah konservasi (peduli lingkungan, cinta lingkungan, tnaggung jawab, kreatif dan objektif) (Savitri et al. 2016).

Bahan ajar secara umum digunakan sebagai alat bantu proses belajar mengajar. Penggunaan bahan ajar secara langsung dapat membantu proses pembelajaran peserta didik. Bahan ajar dapat meningkatkan konsep pada peserta didik (Syar, 2017). Adanya bahan ajar ekologi diharapkan mampu meningkatkan motivasi, kompetensi dan prestasi belajar (Husain et al. 2019). Perguruan tinggi melakukan pemanfaatan nilai ekologi ekosistem mangrove sebagai media pembelajaran bagi peserta didik. Penggunaan media pembelajaran pada alam sekitar memiliki tujuan agar peserta didik mampu mengenali lingkungan dan dapat melakukan konservasi terhadap lingkungan yang rusak. Oleh karena itu, peneliti tertarik untuk melakukan pengabdian dengan judul pemanfaatan nilai ekologi ekosistem mangrove sebagai sumber belajar IPA di SMAN 3 Lembar.

\section{Metode}

1. Observasi

Observasi bertujuan untuk mengetahui lokasi sekolah, kondisi sekolah, alokasi waktu mata pelajaran yang terkait dan pengantaran Surat Izin Pengabdian tentang "Pemanfaatan Nilai Ekologi Ekosistem Mangrove Sebagai Sumber Belajar IPA di SMAN 3 Lembar"

2. Sosialisasi

Sosialisasi dilakukan untuk memperkenalkan kegiatan pengabdian tentang pemanfaatan nilai ekologi ekosistem mangrove sebagai sumber belajar IPA. Hal ini bertujuan untuk memperkenalkan pada peserta didik tentang ekosistem mangrove dan pemanfaatan lingkungan sekitar sebagai sumber belajar IPA. Sehingga proses pembelajaran lebih menarik bagi peserta didik

3. Metode Praktek

Tim pengabdian melakukan penyampaian materi kepada peserta didik dengan metode ceramah. Setelah penyampaian materi selesai dilakukan kegiatan diskusi dan tanya jawab tentang materi ekosistem mangrove yang telah disampaikan oleh tim pengabdian. Kemudian tim pengabdian membentuk peserta didik menjadi 4 kelompok, masing-masing kelompok terdiri dari 3-4 orang. Setelah terbentuk kelompok, tim pengabdian membagikan LKPD untuk dikerjakan oleh peserta didik.

4. Tahap Evaluasi dan Pelaporan

Pelaksanaan evaluasi dilakukan setelah tim pengabdian melakukan kegiatan. Evaluasi dilaksanakan dengan membagi angket 
yang telah disediakan oleh tim pengabdian. Lembar angket bertujuan untuk mengetahui minat peserta didik terkait dengan materi ekosistem mangrove yang telah disampaikan selama pengabdian. Pelaporan berupa hasil analisis angket yang didapatkan akan dibuat berupa presentasi nilai minat peserta didik dalam memanfaatkan lingkungan sekitar sebagai sumber belajar IPA.

5. Analisis Data

Analisis data dilakukan untuk mengetahui sejauh mana minat peserta didik dalam memanfaatkan lingkungan sekitar sebagai sumber belajar IPA khususnya pada materi ekosistem. Hal ini dapat dilihat pada hasil lembar angket yang telah diisi oleh peserta didik dan dihitung dengan menggunakan rating scale (skala penilaian) sebagai berikut:

\begin{tabular}{|c|c|}
\hline Skala & Kategori \\
\hline 1 & Kurang Baik \\
\hline 2 & Baik \\
\hline 3 & Sangat Baik \\
\hline
\end{tabular}

\section{Hasil dan Pembahasan}

SMA 3 Lembar adalah sekolah menengah atas negeri yang berasa di Lembar desa Mareje Timur Kecamatan Lembar. SMA 3 Lembar menjadi salah satu sekolah menengah yang melaksanakan simulasi pembelajaran secara tatap muka di era New Normal Covid-19. Pembelajaran dilakukan di kelas. Pelaksanaan proses pembelajaran di sekolah dilakukan dengan menaati protokol kesehatan Covid-19. Sesuai dengan pemerintahan penerapan sosial distancing di kelas telah dilakukan dengan baik, dimana setiap tenaga akademik, pendidik dan siswa wajib menggunakan masker. Selain itu, dilakukan perubahan aloksi waktu pelaksanaan pembelajaran yang diakibatkan dari Covid-19. Pelaksanaan kegiatan pembelajaran sebelum pandemik dimulai pukul 07.30-02.00 dan setelah pandemik dimulai pukul 07.30 12.00 dengan masing-masing berdurasi 1 jam.

Kegiatan pengabdian adalah salah satu tugas mata kuliah studi mandiri. Tujuan dilakukan kegiatan pengabdian agar mahasiswa dapat mengembangkan atau menerapkan ilmu pengetahuannya secara langsung dalam ruang lingkung masyarakat dibidang akademik. Pelaksanaan kegiatan pengabdian dilakukan berkelompok dengan program berupa pemanfaatn nilai ekologi ekosistem mangrove sebagai sumber belajar IPA. Salah satu program kegiatan yang kami lakukan adalah pengabdian di sekolah dengan sasaran program yaitu peserta didik. Kegiatan program dilakukan untuk mengedukasi peserta didik dalam memanfaatkan lingkungan sekitar sebagai bahan belajar IPA Biologi. Selain itu, kegiatan ini bertujuan untuk menumbuhkan minta peserta didik agar mampu melestarikan lingkungan sekitar.

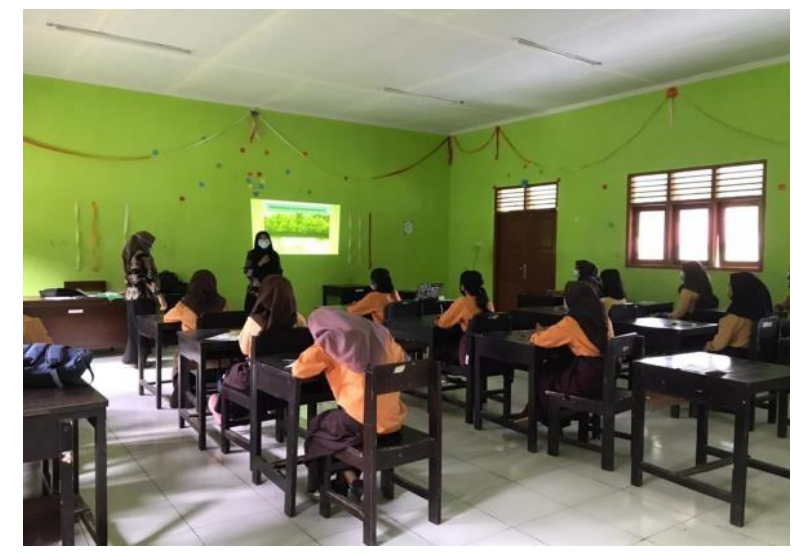

Gambar 1. Kegiatan Sosialisasi Pemanfaatan nilai ekologi ekosistem mangrove sebagai sumber belajar IPA

Berdasarkan angket yang telah diisi oleh peserta didik, respon terkait dengan kegiatan pengabdian yang telah dilakukan menunjukkan bahwa kegiatan pengabdian yang dilakukan sangat baik dan menarik perhatian peserta didik. Hal ini dapat dilihat pada angket yang telah diisi oleh peserta didik menunjukkan pada skala 2 dan 3 yang artinya baik dan sangat baik. Selain itu, pengabdian ini juga dapat menambah ilmu pengetahuan tentang ekosistem mangrove yang jarang diketahui oleh peserta didik. Kemudian dapat melatih peserta didik untuk menggunakan lingkungan sekitar sebagai sumber belajar IPA Biologi. Seperti yang diketahui bahwa pembelajaran IPA sangat dekat dengan kehidupan sehari-hari dan dapat ditemukan pada lingkungan sekitar. 


\section{Kesimpulan}

Berdasarkan rumusan masalah dan pembahasan dapat disipulkan bahwa: Setelah dilakukan pengabdian wawasan peserta didik bertambah terkait dengan ekosistem mangrove. Pemanfaatan lingkungan sekitar salah satunya ekosistem mangrove sebagai sumber belajar IPA menjadi salah satu tambahan belajar untuk membantu meningkatakan pemahaman peserta didik.

\section{Ucapan terima kasih}

Terima kasih penulis sampaikan kepada Dr. Abdul Syukur, M.Si dan Dr. Jamaluddin, M.Pd selaku dosen pembimbing sehingga kami dapat menyelesaikan tugas pengabdian ini dengan baik dan lancer.

\section{Daftar Pustaka}

Donato, D. C., Kauffman, J. B., Murdiyarso, D., Kurnianto, S., Stidham, M., \& Kanninen, M. 2012. Mangrove adalah salah satu hutan terkaya karbon di kawasan tropis. Brief Cifor. 12: 1-10.

Husain, I., Katili, A. S., \& Nusantari, E. 2019. Pengembangan buku ajar ekologi dengan memanfaatkan hasil analisis potensi ekosistem mangrove sebagai penyerap karbon. Jambura Edu Biosfer Journal. 1(1): 23-31.

Saputri, D. N., Winarni, E. W., \& Gunawan, A. 2019. Pengaruh Pemanfaatan Hutan Mangrove sebagai Sumber Belajar IPA terhadap Sikap Peduli Lingkungan Siswa Kelas IV SD Kota Bengkulu. Jurnal PGSD: Jurnal Ilmiah Pendidikan Guru Sekolah Dasar. 12(2): 150-158.

Savitri, E. N., \& Sudarmin, S. 2016. Penerapan pendekatan jas (jelajah alam sekitar) pada mata kuliah konservasi dan kearifan lokal untuk menanamkan softskill konservasi pada mahasiswa ipa unnes. Unnes Science Education Journal. 5(1): 102-107.

Syar, N. I. 2017. Penggunaan Bahan IPA Terpadu dengan Tema Cuaca Untuk
Meningkatkan Penguasaan Konsep IPA. Jurnal Edusains. 9(1): 34-40.

Yokhebed, Y., Titin, T., \& Wahyuni, E. S. 2016. Peningkatan Life Skill melalui Pembelajaran Berbasis Keunggulan Lokal. In Proceeding Biology Education Conference: Biology Science, Enviromental, and Learning. 13(1): 455460. 